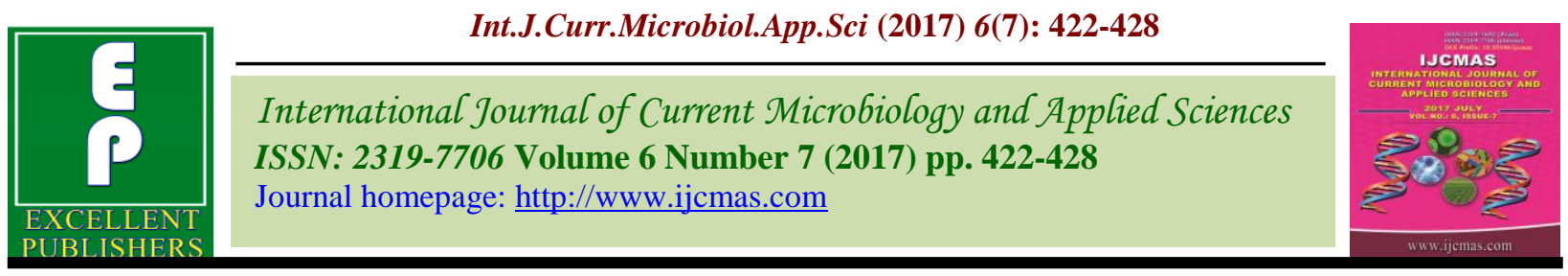

Original Research Article

https://doi.org/10.20546/ijcmas.2017.607.050

\title{
Influence of Different Planting Material and Major Nutrient Application on Yield Attributes of Turmeric (Curcuma longa L.)
}

\author{
A. Neeraja ${ }^{*}$, D.V. Swami, B. Prasanna Kumar, T.S.K.K. Kiran Patro, \\ D.R. Salomi Suneetha and B. Babu Rao \\ College of Horticulture, Dr. Y. S. R. Horticultural University, Venkataramannagudem, \\ West Godavari District-534101, A.P., India \\ *Corresponding author
}

\section{A B S T R A C T}

The experiment was conducted at college farm of Horticultural College and Research Institute, Venkataramannagudem, Andhra Pradesh during 2014-15 to

\section{Keywords}

Planting material, Fertilizer levels,

Turmeric and size of the rhizome.

Article Info

Accepted:

04 June 2017 Available Online: 10 July 2017 determine the effect of different types of planting material and fertilizer levels on quantitative parameters i.e., number and size of mother, primary, secondary rhizomes, fresh and dry weight per clump and yield of turmeric. A total of six types of planting material raised in protrays viz., single node cuttings, double node cuttings, mother rhizome pieces, primary, secondary and mother rhizomes were evaluated with five fertilizer doses in factorial randomized block design. The results on quantitative parameters indicated that these variables were in decreasing order with reduced seed size and fertilizer dose. Mother rhizomes as planting material with the application of 360: $120: 160 \mathrm{~kg} \mathrm{NPK} \mathrm{ha}^{-1}$ recorded the maximum number of mother rhizomes (2.43), number of secondary rhizomes (16.07), size of secondary rhizomes $\left(11.76 \mathrm{~cm}^{3}\right)$, fresh weight of rhizomes clump ${ }^{-1}(238.12 \mathrm{~g})$, dry weight of rhizomes clump ${ }^{-1}(79.58 \mathrm{~g})$ and rhizome yield ha- ${ }^{-1}\left(30.94 \mathrm{tha}^{-1}\right)$ and the least was observed in single node cuttings along with 120: 40: $100 \mathrm{~kg} \mathrm{NPK} \mathrm{ha}^{-1}$.

\section{Introduction}

Turmeric (Curcuma longa $\quad$ L.) is a rhizomatous herbaceous perennial plant belonging to the family Zingiberaceae. Turmeric is native to tropical South-East Asia but is now widely cultivated in the tropical and subtropical regions of the world. It is one of the important spice crops of the tropics. India is the largest producer, consumer and exporter of turmeric in the world. Curcumin is the pigment that lends the bright stunning yellow colour to turmeric which can be used as a dye. It is a sterile triploid and vegetatively propagated through rhizomes.
Since rhizome multiplication is slow and maintenance of planting material is expensive, a rapid multiplication method of low cost through protrays, pathogen free transplants which produce the planting material more effectively than standard seed rhizome is necessary. As seed material cost is very high, there is a need to reduce the cost of seed material by adopting alternative planting material and selecting optimum size rhizome or rhizome cuttings. Increased production of turmeric in the state will help not only to meet its own requirements but also help the country 
to boost its export. Pronounced effect of planting material by raising the seedlings in protrays and varying levels of $\mathrm{N}, \mathrm{P}$ and $\mathrm{K}$ on growth characters of turmeric have been proved separately by many workers. Not much work has been done on turmeric to find out best planting material through raising seedlings along with $\mathrm{N}, \mathrm{P}$ and $\mathrm{K}$ application to get higher yields and their effect on quality of turmeric.

This study was conducted to find out the response of different types of planting material raised in protrays and different levels of fertilizer to ensure better growth and yield along with quality of turmeric.

\section{Materials and Methods}

An experiment was carried during 2014-2015 at the Horticultural College and Research Institute, Venkataramannagudem, West Godavari District, Andhra Pradesh. A total of six types of planting materials were taken viz. Single node cuttings of primary rhizome (5-6 g), Two node cuttings of primary rhizome (8$9 \mathrm{~g})$, Mother rhizome pieces (10-12 g), Primary rhizomes (20-25 g), Secondary rhizomes (8-10 g), Mother rhizomes (75-90 g) with five fertilizer levels viz. 120:40:100 kg NPK ha ${ }^{-1}, \quad 180: 60: 115$ kg NPK ha ${ }^{-1}$, 240:80:130 kg NPK ha-1, 300:100:145 kg NPK ha ${ }^{-1}$ and 360:120:160 kg NPK ha-1. There were thirty treatment combinations replicated three times in Factorial Randomized Block Design (FRBD).

Available nitrogen, phosphorous and potassium in the soil were determined by Modified Kjeldahl method (Jackson et al., 1973), Olsen's method (Olsen et al., 1954) and Flame Photometer method (Muhr et al., 1965) respectively. The selected Duggirala White variety was a typical medium duration variety with 7-8 months crop period. Initially seed rhizomes were laid in a nursery with shade net and 1month old seedlings were transplanted in the main field. The crop was fertilized with nitrogen, phosphorus and potassium according to the dosage scheduled in the experiment. The NPK fertilizers were applied in the form of Urea, Single Super Phosphate and Muriate of Potash respectively. The entire dose of $\mathrm{P}$ was applied as basal, while $\mathrm{N}$ and $\mathrm{K}$ were applied in three equal splits during the crop growth. Entire crop protection measures and intercultural operations were followed as per the recommendation where ever the crop needed.

The crop was harvested 8 months after raising. Quantitative parameters viz., number and size of mother, primary, secondary rhizomes, fresh and dry weight per clump and yield were determined after harvest. The number of mother, primary and secondary rhizomes was calculated by selecting five random plants. As well as size of mother primary and secondary rhizomes was recorded by water displacement method. Fresh and dry weight of the rhizomes clump ${ }^{-1}$ was taken by recording fresh weight immediately after harvest and dry weight after oven drying process. The gross plot yield was computed for one hectare and expressed as fresh yield per hectare in tonnes.

\section{Results and Discussion}

Among the different type of planting materials, mother rhizomes recorded significantly the highest values in different parameters at almost all yield parameters. The number of mother rhizomes (2.72), number of primary rhizomes (10.79), size of primary rhizomes $\left(24.39 \mathrm{~cm}^{3}\right)$, size of secondary rhizomes $\left(11.24 \mathrm{~cm}^{3}\right)$, fresh weight of rhizomes clump ${ }^{-1}(212.09 \mathrm{~g})$, dry weight of rhizomes clump ${ }^{-1}(68.51 \mathrm{~g})$, rhizome yield ha ${ }^{-1}$ $\left(27.57 \mathrm{t} \mathrm{ha}^{-1}\right)$ were recorded highest with the mother rhizomes when used as planting material which was significantly superior to single node cuttings. 
Table.1 Effect of type of planting material and fertilizer levels on number of rhizomes clump ${ }^{-1}$ in turmeric (Curcuma longa L.) $^{-}$

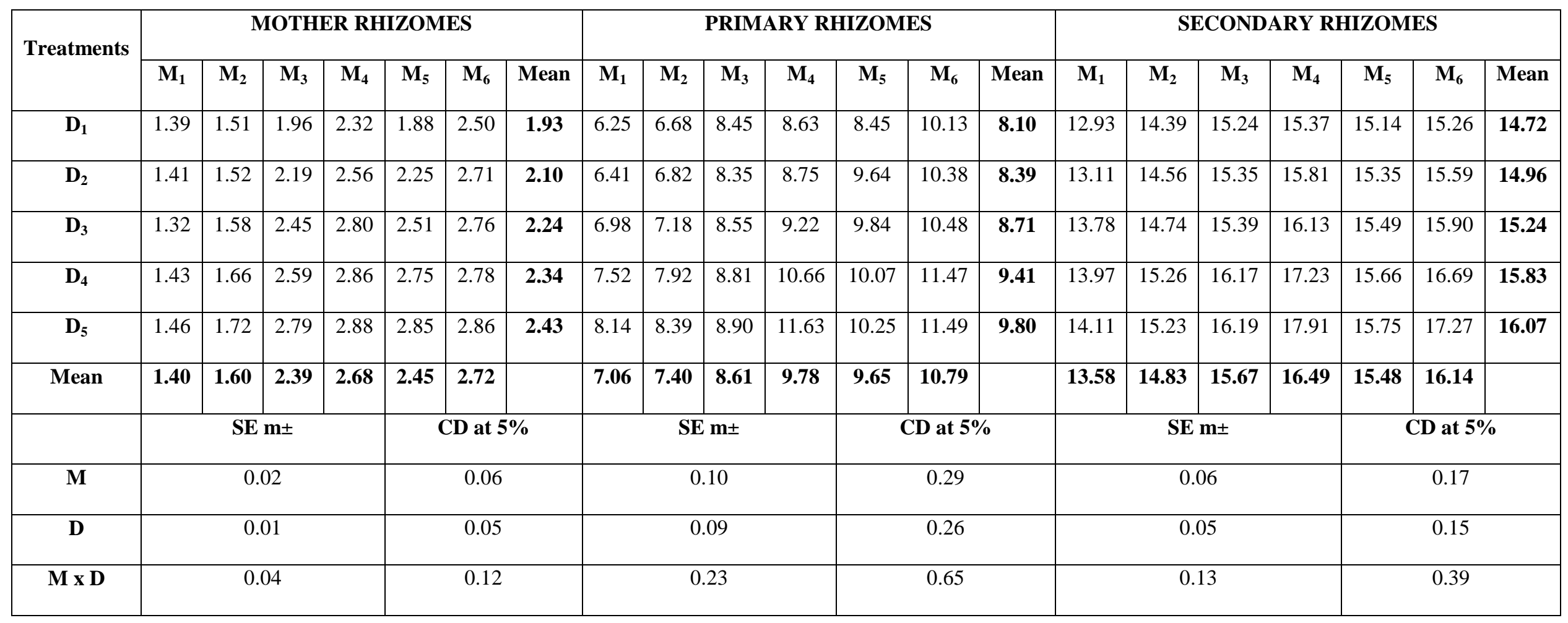

\section{Factor-1 Planting material (M)}

$\mathrm{M}_{1}$ : Seedlings raised from single node cuttings of primary rhizome (5-6 g)

$\mathrm{M}_{2}$ : Seedlings raised from two node cuttings of primary rhizomes $(8-9 \mathrm{~g})$

$\mathrm{M}_{3}$ : Seedlings raised from mother rhizome pieces (10-12 g)

$\mathrm{M}_{4}$ : Seedlings raised from primary rhizome (20-25 g)

$\mathrm{M}_{5}$ : Seedlings raised fromsecondary rhizomes (8-10 g)

$\mathrm{M}_{6}$ : Seedlings raised frommother rhizomes (75-90 g)

\section{Factor -2Fertilizer dose (D)}

$\mathrm{D}_{1}: 120: 40: 100 \mathrm{~kg} \mathrm{NPK} \mathrm{ha}^{-1}$

$\mathrm{D}_{2}: 180: 60: 115 \mathrm{~kg} \mathrm{NPK} \mathrm{ha}{ }^{-1}$

$\mathrm{D}_{3}: 240: 80: 130 \mathrm{~kg} \mathrm{NPK} \mathrm{ha}^{-1}$

$\mathrm{D}_{4}: 300: 100: 145 \mathrm{~kg}$ NPK ha ${ }^{-1}$

$\mathrm{D}_{5}: 360: 120: 160 \mathrm{~kg} \mathrm{NPK} \mathrm{ha}{ }^{-1}$

DAP- Days after planting 
Table.2 Effect of type of planting material and fertilizer levels on size of rhizomes $\left(\mathrm{cm}^{3}\right)$ in turmeric (Curcuma longa L.)

\begin{tabular}{|c|c|c|c|c|c|c|c|c|c|c|c|c|c|c|c|c|c|c|c|c|c|}
\hline \multirow{2}{*}{ Treatments } & \multicolumn{7}{|c|}{ MOTHER RHIZOMES } & \multicolumn{7}{|c|}{ PRIMARY RHIZOMES } & \multicolumn{7}{|c|}{ SECONDARY RHIZOMES } \\
\hline & $\mathbf{M}_{1}$ & $\mathbf{M}_{2}$ & $\mathbf{M}_{3}$ & $\mathbf{M}_{4}$ & $\mathbf{M}_{5}$ & $\mathbf{M}_{6}$ & Mean & $\mathbf{M}_{1}$ & $\mathbf{M}_{2}$ & $\mathbf{M}_{3}$ & $\mathbf{M}_{4}$ & $\mathbf{M}_{5}$ & $\mathbf{M}_{6}$ & Mean & $\mathbf{M}_{1}$ & $\mathbf{M}_{2}$ & $\mathbf{M}_{3}$ & $\mathbf{M}_{4}$ & $\mathbf{M}_{5}$ & $\mathbf{M}_{6}$ & Mean \\
\hline $\mathbf{D}_{1}$ & 17.02 & 21.42 & 30.15 & 43.64 & 26.75 & 45.92 & 30.82 & 8.60 & 9.87 & 19.78 & 21.09 & 18.39 & 22.87 & 16.77 & 2.07 & 4.26 & 8.15 & 9.47 & 5.61 & 10.41 & 6.66 \\
\hline $\mathbf{D}_{2}$ & 17.29 & 22.11 & 31.82 & 45.27 & 27.35 & 47.82 & 33.61 & 8.66 & 10.23 & 21.10 & 21.58 & 18.59 & 23.51 & 17.28 & 2.41 & 4.64 & 8.21 & 10.32 & 6.33 & 10.93 & 7.14 \\
\hline $\mathbf{D}_{3}$ & 18.42 & 22.83 & 33.37 & 47.71 & 28.12 & 49.44 & 33.31 & 9.12 & 10.67 & 22.05 & 22.52 & 19.08 & 24.39 & 17.97 & 2.64 & 4.92 & 8.43 & 10.92 & 7.05 & 11.37 & 7.55 \\
\hline $\mathbf{D}_{4}$ & 19.51 & 24.23 & 34.19 & 48.67 & 30.00 & 50.57 & 34.57 & 9.24 & 10.74 & 22.63 & 23.61 & 20.38 & 24.60 & 18.58 & 2.89 & 5.09 & 8.81 & 11.67 & 7.36 & 11.73 & 7.92 \\
\hline $\mathbf{D}_{5}$ & 20.89 & 25.30 & 34.33 & 49.37 & 32.50 & 50.82 & 35.49 & 9.61 & 10.90 & 23.30 & 23.84 & 21.41 & 24.89 & 18.94 & 3.02 & 5.19 & 9.29 & 11.50 & 7.63 & 11.76 & 8.06 \\
\hline \multirow[t]{2}{*}{ Mean } & 18.62 & 23.18 & 32.77 & 48.93 & 28.94 & 48.91 & & 9.04 & 10.48 & 21.77 & 22.53 & 19.57 & 24.39 & & 2.61 & 4.82 & 8.58 & 10.77 & 6.79 & 11.24 & \\
\hline & \multicolumn{4}{|c|}{ SE $\mathbf{m} \pm$} & \multicolumn{3}{|c|}{ CD at 5\% } & \multicolumn{4}{|c|}{ SE $\mathbf{m} \pm$} & \multicolumn{3}{|c|}{ CD at $5 \%$} & \multicolumn{4}{|c|}{ SE $\mathbf{m} \pm$} & \multicolumn{3}{|c|}{ CD at $5 \%$} \\
\hline $\mathbf{M}$ & \multicolumn{4}{|c|}{0.775} & \multicolumn{3}{|c|}{2.197} & \multicolumn{4}{|c|}{0.063} & \multicolumn{3}{|c|}{0.178} & \multicolumn{4}{|c|}{0.044} & \multicolumn{3}{|c|}{0.124} \\
\hline D & \multicolumn{4}{|c|}{0.708} & \multicolumn{3}{|c|}{2.005} & \multicolumn{4}{|c|}{0.057} & \multicolumn{3}{|c|}{0.163} & \multicolumn{4}{|c|}{0.040} & \multicolumn{3}{|c|}{0.113} \\
\hline M $\times D$ & \multicolumn{4}{|c|}{1.735} & \multicolumn{3}{|c|}{ NS } & \multicolumn{4}{|c|}{0.141} & \multicolumn{3}{|c|}{0.399} & \multicolumn{4}{|c|}{0.098} & \multicolumn{3}{|c|}{0.279} \\
\hline
\end{tabular}

\section{Factor-1 Planting material (M)}

$\mathrm{M}_{1}$ : Seedlings raised from single node cuttings of primary rhizome (5-6 g) $\mathrm{M}_{2}$ : Seedlings raised from two node cuttings of primary rhizomes (8-9 g)

$\mathrm{M}_{3}$ : Seedlings raised from mother rhizome pieces (10-12 $\mathrm{g}$ )

$\mathrm{M}_{4}$ : Seedlings raised from primary rhizome (20-25 g)

$\mathrm{M}_{5}$ : Seedlings raised fromsecondary rhizomes (8-10 g)

$\mathrm{M}_{6}$ : Seedlings raised frommother rhizomes (75-90 g)

\section{Factor -2Fertilizer dose (D)}

$\mathrm{D}_{1}: 120: 40: 100 \mathrm{~kg} \mathrm{NPK} \mathrm{ha}^{-1}$

$\mathrm{D}_{2}: 180: 60: 115 \mathrm{~kg} \mathrm{NPK} \mathrm{ha}^{-1}$

$\mathrm{D}_{3}: 240: 80: 130 \mathrm{~kg} \mathrm{NPK} \mathrm{ha}^{-1}$

$\mathrm{D}_{4}: 300: 100: 145 \mathrm{~kg} \mathrm{NPK} \mathrm{ha}{ }^{-1}$

$\mathrm{D}_{5}: 360: 120: 160 \mathrm{~kg}$ NPK ha ${ }^{-1}$ 
Table.3 Effect of type of planting material and fertilizer levels on fresh and dry weight ( $\mathrm{g} \mathrm{clump}^{-1}$ ) of rhizomes (Curcuma longa $\mathrm{L}$.)

\begin{tabular}{|c|c|c|c|c|c|c|c|c|c|c|c|c|c|c|}
\hline \multirow{2}{*}{ Treatments } & \multicolumn{7}{|c|}{ FRESH WEIGHT OF RHIZOMES } & \multicolumn{7}{|c|}{ DRY WEIGHT OF RHIZOMES } \\
\hline & $\mathbf{M}_{1}$ & $\mathbf{M}_{2}$ & $\mathbf{M}_{3}$ & $\mathbf{M}_{4}$ & $\mathbf{M}_{5}$ & $\mathbf{M}_{6}$ & Mean & $\mathbf{M}_{1}$ & $\mathbf{M}_{2}$ & $\mathbf{M}_{3}$ & $\mathbf{M}_{4}$ & $\mathbf{M}_{5}$ & $\mathbf{M}_{6}$ & Mean \\
\hline $\mathbf{D}_{1}$ & 74.00 & 84.67 & 99.17 & 188.11 & 99.75 & 185.63 & 121.89 & 33.91 & 36.40 & 42.60 & 54.08 & 37.68 & 60.22 & 44.15 \\
\hline $\mathbf{D}_{2}$ & 78.66 & 98.26 & 106.34 & 195.93 & 108.81 & 202.81 & 131.80 & 35.88 & 37.85 & 45.27 & 56.04 & 40.39 & 62.38 & 46.30 \\
\hline $\mathbf{D}_{3}$ & 91.71 & 105.99 & 119.97 & 202.44 & 113.00 & 217.63 & 141.79 & 36.77 & 39.49 & 47.56 & 58.99 & 44.29 & 68.38 & 49.25 \\
\hline $\mathbf{D}_{4}$ & 94.40 & 111.25 & 136.72 & 218.70 & 132.23 & 223.28 & 152.76 & 47.91 & 50.79 & 51.00 & 65.34 & 46.14 & 71.97 & 55.52 \\
\hline $\mathbf{D}_{5}$ & 99.61 & 125.49 & 143.35 & 231.14 & 152.23 & 238.12 & 164.99 & 49.25 & 52.60 & 55.15 & 75.03 & 49.34 & 79.58 & 60.16 \\
\hline \multirow[t]{2}{*}{ Mean } & 87.68 & 105.13 & 121.11 & 208.66 & 121.20 & 212.09 & & 40.74 & 43.42 & 48.32 & 61.89 & 43.57 & 68.51 & \\
\hline & \multicolumn{4}{|c|}{ SE $\mathbf{m} \pm$} & \multicolumn{3}{|c|}{ CD at $5 \%$} & \multicolumn{4}{|c|}{ SE $\mathbf{m} \pm$} & \multicolumn{3}{|c|}{ CD at $5 \%$} \\
\hline $\mathbf{M}$ & \multicolumn{4}{|c|}{0.934} & \multicolumn{3}{|c|}{1.32} & \multicolumn{4}{|c|}{0.449} & \multicolumn{3}{|c|}{1.271} \\
\hline D & \multicolumn{4}{|c|}{0.852} & \multicolumn{3}{|c|}{1.20} & \multicolumn{4}{|c|}{0.409} & \multicolumn{3}{|c|}{1.160} \\
\hline$M \times D$ & \multicolumn{4}{|c|}{2.088} & \multicolumn{3}{|c|}{5.91} & \multicolumn{4}{|c|}{1.004} & \multicolumn{3}{|c|}{2.843} \\
\hline
\end{tabular}

\section{Factor-1 Planting material (M)}

$\mathrm{M}_{1}$ : Seedlings raised from single node cuttings of primary rhizome (5-6 g)

$\mathrm{M}_{2}$ : Seedlings raised from two node cuttings of primary rhizomes (8-9 g)

$\mathrm{M}_{3}$ : Seedlings raised from mother rhizome pieces (10-12 $\mathrm{g}$ )

$\mathrm{M}_{4}$ : Seedlings raised from primary rhizome (20-25 g)

$\mathrm{M}_{5}$ : Seedlings raised fromsecondary rhizomes $(8-10 \mathrm{~g})$

$\mathrm{M}_{6}$ : Seedlings raised frommother rhizomes (75-90 g)
Factor -2Fertilizer dose (D)

$\mathrm{D}_{1}: 120: 40: 100 \mathrm{~kg} \mathrm{NPK} \mathrm{ha}^{-1}$

$\mathrm{D}_{2}: 180: 60: 115 \mathrm{~kg} \mathrm{NPK} \mathrm{ha}^{-1}$

$\mathrm{D}_{3}: 240: 80: 130 \mathrm{~kg} \mathrm{NPK} \mathrm{ha}^{-1}$

$\mathrm{D}_{4}: 300: 100: 145 \mathrm{~kg} \mathrm{NPK} \mathrm{ha}^{-1}$

$\mathrm{D}_{5}: 360: 120: 160 \mathrm{~kg} \mathrm{NPK} \mathrm{ha}^{-1}$ 
Table.4 Effect of type of planting material and fertilizer levels on rhizome yield ( $\mathrm{tha}^{-1}$ ) in turmeric (Curcuma longa L.)

\begin{tabular}{|c|c|c|c|c|c|c|c|}
\hline \multirow{2}{*}{ Treatments } & \multicolumn{7}{|c|}{ RHIZOME YIELD } \\
\hline & $\mathbf{M}_{1}$ & $\mathbf{M}_{2}$ & $\mathbf{M}_{3}$ & $\mathbf{M}_{4}$ & $\mathbf{M}_{5}$ & $\mathbf{M}_{6}$ & Mean \\
\hline $\mathbf{D}_{1}$ & 9.62 & 11.00 & 12.89 & 24.45 & 12.96 & 24.13 & 15.84 \\
\hline $\mathbf{D}_{2}$ & 10.22 & 12.77 & 13.82 & 25.47 & 14.14 & 26.36 & 17.13 \\
\hline $\mathbf{D}_{3}$ & 11.92 & 13.77 & 15.59 & 26.31 & 14.69 & 28.29 & 18.43 \\
\hline $\mathbf{D}_{4}$ & 12.27 & 14.46 & 17.77 & 28.43 & 17.19 & 29.02 & 19.85 \\
\hline$D_{5}$ & 12.95 & 16.31 & 18.63 & 30.05 & 19.79 & 30.94 & 21.44 \\
\hline \multirow[t]{2}{*}{ Mean } & 11.39 & 13.66 & 15.74 & 27.12 & 15.75 & 27.57 & \\
\hline & \multicolumn{4}{|c|}{ SE m \pm} & \multicolumn{3}{|c|}{ CD at $5 \%$} \\
\hline $\mathbf{M}$ & \multicolumn{4}{|c|}{1.21} & \multicolumn{3}{|c|}{3.43} \\
\hline D & \multicolumn{4}{|c|}{1.10} & \multicolumn{3}{|c|}{3.13} \\
\hline$M \times D$ & \multicolumn{4}{|c|}{2.71} & \multicolumn{3}{|c|}{7.68} \\
\hline
\end{tabular}

\section{Factor-1 Planting material (M)}

$\mathrm{M}_{1}$ : Seedlings raised from single node cuttings of primary rhizome (5-6 g)

$\mathrm{M}_{2}$ : Seedlings raised from two node cuttings of primary rhizomes (8-9 $\mathrm{g}$ )

$\mathrm{M}_{3}$ : Seedlings raised from mother rhizome pieces (10-12 g)

$\mathrm{M}_{4}$ : Seedlings raised from primary rhizome (20-25 g)

$\mathrm{M}_{5}$ : Seedlings raised fromsecondary rhizomes $(8-10 \mathrm{~g})$

$\mathrm{M}_{6}$ : Seedlings raised frommother rhizomes (75-90 g)

\section{Factor -2Fertilizer dose (D)}

$\mathrm{D}_{1}:$ 120:40:100kg NPK ha ${ }^{-1}$

$\mathrm{D}_{2}: 180: 60: 115 \mathrm{~kg} \mathrm{NPK} \mathrm{ha}^{-1}$

$\mathrm{D}_{3}: 240: 80: 130 \mathrm{~kg} \mathrm{NPK} \mathrm{ha}^{-1}$

$\mathrm{D}_{4}: 300: 100: 145 \mathrm{~kg} \mathrm{NPK} \mathrm{ha}^{-1}$

$\mathrm{D}_{5}: 360: 120: 160 \mathrm{~kg} \mathrm{NPK} \mathrm{ha}^{-1}$ 
Number of mother rhizomes (2.43), number of primary rhizomes (9.80), number of secondary rhizomes (16.07) (Table 1), size of mother rhizomes $\left(35.49 \mathrm{~cm}^{3}\right)$, size of primary rhizomes $\left(18.94 \mathrm{~cm}^{3}\right)$, size of secondary rhizomes $(8.06$ $\left.\mathrm{cm}^{3}\right)$, fresh weight of rhizomes clump ${ }^{-1}(121.89 \mathrm{~g})$, dry weight of rhizomes clump ${ }^{-1}(60.16 \mathrm{~g})$, rhizome yield ha $\mathrm{ha}^{-1}\left(21.44 \mathrm{t} \mathrm{ha}^{-1}\right)$ were recorded with 360:120:160 kg NPK ha ${ }^{-1}$ applied as fertilizer dose which was significantly superior to 120:40:100 kg NPK ha' (Table 3). Among the interaction effects between different types of planting material and fertilizer levels, mother rhizomes along with the application of 360:120:160 kg NPK ha ${ }^{-1}$ recorded significantly the highest values in different yield parameters like number of mother rhizomes (2.43), number of secondary rhizomes (16.07), size of secondary rhizomes $\left(11.76 \mathrm{~cm}^{3}\right)$, fresh weight of rhizomes clump $^{-1}(238.12 \mathrm{~g})$, dry weight of rhizomes clump ${ }^{1}(79.58 \mathrm{~g})$, rhizome yield $\mathrm{ha}^{-1}\left(30.94 \mathrm{t} \mathrm{ha}^{-1}\right)$ with the mother rhizomes in combination with 360:120:160 kg NPK ha ${ }^{-1}$ which was significantly superior to single node cuttings with 120:40:100 $\mathrm{kg}$ NPK ha ${ }^{-1}$ (Tables 1-4). Similar results were reported in turmeric (Meenakshi et al., 1995 and Manhas et al., 2012).

The differences in the rhizome yield might be due to different planting materials being able to relate to the difference in the dry matter and biomass production of the plant. Number of primary fingers plant $^{-1}$ contributed more towards the rhizome yield. The circumference of the primary fingers in mother rhizomes was more as compared to other types of planting material. This may be due to translocation and mobilization of assimilates and nutrients from the source which is more in the mother rhizome, from where they are further translocated and accumulated in fingers making the mother rhizome quantitatively and qualitatively superior. Reddy et al., (2015) reported the highest yield in turmeric was obtained by the combination of $\mathrm{N} @ 180 \mathrm{~kg} \mathrm{ha}^{-1}$, P@120 kg ha ${ }^{-1}$ and $\mathrm{K} @ 100 \mathrm{~kg} \mathrm{ha}^{-1}$, thus signifying the role of nutrients in getting higher in turmeric. The differences in the rhizome yield in the present study may be due to the differences in the vegetative growth like number tillers, number of leaves and plant height etc. The differences in the number and size of mother, primary and secondary rhizomes plant ${ }^{-1}$ obtained as a result of graded doses of N, P and $\mathrm{K}$ could also attributed for such a difference in the rhizome yields.

\section{References}

Jackson, M.L. 1973. Soil chemical analysis. Prentice - Hall of India Private Limited, New Delhi.

Manhas, S.S. and Gill, B.S.2012. Effect of different cultural practices of turmeric (Curcuma longa) in Punjab. Journal of Spices and Aromatic crops. 21(1): 53-58.

Meenakshi, N., Sulikeri, G.B., Ramakrishna, V. and Hegde. 1999. Effect of planting material and $\mathrm{P}$ and $\mathrm{K}$ on plant growth of turmeric. Karnataka Journal of Agricultural Sciences. 14(1):194-196.

Muhr, G.R. 1965. Soil testing in India, USAID, New Delhi. 120.

Olsen, S.R., Cole, C.V., Watanabe, F.S. and Dean, L.A. 1954. Estimation of available phosphorus in soils by extraction with $\mathrm{NaHCO}_{3}$. Cir. U.S. Dept. Agric. 939.

Reddy, D.V.R., Maruthi, S.G.R., Subbaiah, K.R., Sreenivasa, C.M., Sharma, S.H. K., Pushpanjali, N., Visha, K.V. and Sravani, P.N. 2015. Soil-Plant-Fertilizer relationships in turmeric assessment of Soil-PlantFertilizer-Nutrient relationships for sustainable productivity of turmeric under Alfisols and Inceptisols in Southern India. Communications in Soil Science and Plant Analysis. 46: 781-99.

\section{How to cite this article:}

Neeraja, A., D.V. Swami, B. Prasanna Kumar, T.S.K.K. Kiran Patro, D.R. Salomi Suneetha and Babu Rao, B. 2017. Influence of Different Planting Material and Major Nutrient Application on Yield Attributes of Turmeric (Curcuma longa L.). Int.J.Curr.Microbiol.App.Sci. 6(7): 422-428. doi: https://doi.org/10.20546/ijcmas.2017.607.050 